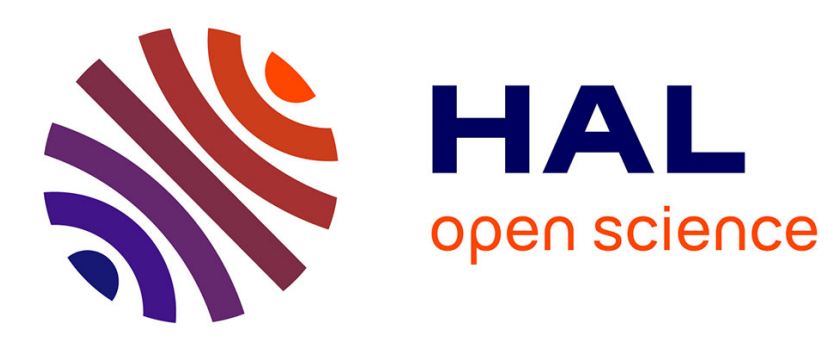

\title{
A Comparative Analysis of Hijras and Drag Queens Sandeep Bakshi
}

\section{To cite this version:}

Sandeep Bakshi. A Comparative Analysis of Hijras and Drag Queens. Journal of Homosexuality, 2004, 46 (3-4), pp.211-223. 10.1300/j082v46n03_13. hal-01964449

\section{HAL Id: hal-01964449 \\ https://hal.science/hal-01964449}

Submitted on 8 Jan 2019

HAL is a multi-disciplinary open access archive for the deposit and dissemination of scientific research documents, whether they are published or not. The documents may come from teaching and research institutions in France or abroad, or from public or private research centers.
L'archive ouverte pluridisciplinaire HAL, est destinée au dépôt et à la diffusion de documents scientifiques de niveau recherche, publiés ou non, émanant des établissements d'enseignement et de recherche français ou étrangers, des laboratoires publics ou privés. 
This article was downloaded by: [University of Leicester]

On: 23 June 2010

Access details: Access Details: [subscription number 773557639]

Publisher Routledge

Informa Ltd Registered in England and Wales Registered Number: 1072954 Registered office: Mortimer House, 3741 Mortimer Street, London W1T 3JH, UK

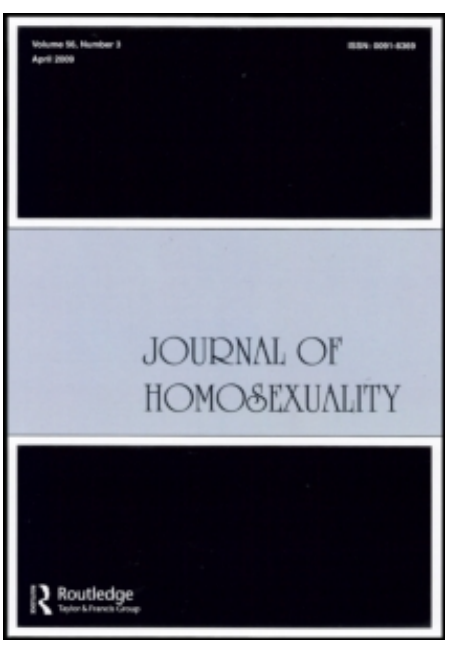

\section{Journal of Homosexuality}

Publication details, including instructions for authors and subscription information:

http://www.informaworld.com/smpp/title content=t792306897

\section{A Comparative Analysis of Hijras and Drag Queens}

Sandeep Bakshi ${ }^{\mathrm{a}}$

${ }^{a}$ Department of English, University of Rouen,

To cite this Article Bakshi, Sandeep(2004) 'A Comparative Analysis of Hijras and Drag Queens', Journal of Homosexuality, 46: $3,211-223$

To link to this Article: DOI: $10.1300 / J 082 v 46 n 03 \_13$

URL: http://dx.doi.org/10.1300/J082v46n03_13

\section{PLEASE SCROLL DOWN FOR ARTICLE}

Full terms and conditions of use: http://www.informaworld.com/terms-and-conditions-of-access.pdf

This article may be used for research, teaching and private study purposes. Any substantial or systematic reproduction, re-distribution, re-selling, loan or sub-licensing, systematic supply or distribution in any form to anyone is expressly forbidden.

The publisher does not give any warranty express or implied or make any representation that the contents will be complete or accurate or up to date. The accuracy of any instructions, formulae and drug doses should be independently verified with primary sources. The publisher shall not be liable for any loss, actions, claims, proceedings, demand or costs or damages whatsoever or howsoever caused arising directly or indirectly in connection with or arising out of the use of this material. 


\title{
A Comparative Analysis of Hijras and Drag Queens: The Subversive Possibilities and Limits of Parading Effeminacy and Negotiating Masculinity
}

\author{
Sandeep Bakshi \\ University of Rouen
}

\begin{abstract}
SUMMARY. Gender studies in general and queer studies in particular have stressed the notion of imitation, play, and performance of gender. In this essay I undertake a comparative analysis of the hijra and the drag queen in terms of the shared and disparate subversive possibilities and
\end{abstract}

Sandeep Bakshi is a PhD candidate in the Department of English at the University of Rouen.

Author note: I thank Harjot Bhatia for reading earlier drafts of this article and giving me valuable suggestions. Many thanks to Kavita and Manish, to my partner Frédéric, to my mother and father, and to Mohammed Sow, whose various forms of support have made this paper possible. Special thanks to Steven P. Schacht for not giving up on me.

Correspondence may be addressed: Sandeep Bakshi, c/o Professor Jean Pierre Maquerlot, Department of English, Faculté de Lettres, University of Rouen, Mont Saint Aignan, 76821, France (E-mail: bakshisandip@aol.com).

[Haworth co-indexing entry note]: “A Comparative Analysis of Hijras and Drag Queens: The Subversive Possibilities and Limits of Parading Effeminacy and Negotiating Masculinity.” Bakshi, Sandeep. Co-published simultaneously in Journal of Homosexuality (Harrington Park Press, an imprint of The Haworth Press, Inc.) Vol. 46, No. 3/4, 2004, pp. 211-223; and: The Drag Queen Anthology: The Absolutely Fabulous but Flawlessly Customary World of Female Impersonators (ed: Steven P. Schacht, with Lisa Underwood) Harrington Park Press, an imprint of The Haworth Press, Inc., 2004, pp. 211-223. Single or multiple copies of this article are available for a fee from The Haworth Document Delivery Service [1-800-HAWORTH, 9:00 a.m. - 5:00 p.m. (EST). E-mail address: docdelivery@haworthpress.com].

http://www.haworthpress.com/web/JH

(C) 2004 by The Haworth Press, Inc. All rights reserved.

Digital Object Identifier: 10.1300/J082v46n03_13 
limits of the gendered performances they undertake. Studying the hijra alongside the drag queen will in no way mean conflating the two categories. Rather, I explore the cultural nuances involved in the hijra performance, including its ritualistic and religious aspects. While my analysis relies heavily on previously written works about hijras and drag queens, I have also had the opportunity to meet and visit with hijras during several marriage ceremonies of cousins and other relatives from 1992 to 1998 in New Delhi. [Article copies available for a fee from The Haworth Document Delivery Service: 1-800-HAWORTH. E-mail address: <docdelivery@ haworthpress.com> Website: <http://www.HaworthPress.com> (C) 2004 by The Haworth Press, Inc. All rights reserved.]

KEYWORDS. Hijras, drag queens, gender as performance, effeminacy, masculinity, Hindu culture

In the following paper I offer a queer reading of the hijra in terms of the subversive possibilities and limits such individuals pose to established modes of thinking about gender binaries. I analyze the hijra alongside that of the much discussed and debated western figure of the drag queen. However, a comparative analysis of the hijra versus the drag queen does not mean advocating the critical meaningfulness of the one over the other. Rather, in this article, I relocate both of these cultural models as potentially destabilizing to contemporary understandings of gendered and sexed identities. The notion of gender as performance as a transcultural "tool" for dismantling rigidities of the masculine/feminine divide is discussed in detail. I make it clear, however, that the hijra figure is not the Indian counterpart of, nor the Indian answer to, the drag queen. The hijra community is an integrated and inseparable part of the Indian social fabric and is "undoubtedly related to the variety and significance of alternative gender roles and gender transformations in Indian mythology and traditional culture" (Nanda, 1999, p. 20).

\section{HIJRAS AND HINDU CULTURE}

Hijras belong to the category of sexually "ambivalent" men-minus man-who dress up as women and perform on auspicious Hindu occasions like weddings and birth ceremonies (O'Flaherty, 1980, p. 297). Official counts of hijras vary significantly from 50,000 to upwards of 
1.2 million (Bobb and Patel, 1982; Hall, 1997, p. 431; Jaffrey, 1997, p. 30; $B B C$ News Online, 2001). While a few Hijras are born intersexed (which is rare), most are men who undergo voluntary castration and penectomy while "possessed" by the Goddess Bahuchara (Cohen, 1995, p. 276). They consider themselves to be sexually impotent, an important point which I will discuss later in the essay. Hijras have cultural and ritual sanction during wedding and birth ceremonies, and even the colonial rulers in the nineteenth century had to concede to their rights of property and begging for alms that they had hitherto enjoyed under native rulers (Preston, 1987).

Hijras live in large communities in North India and Pakistan, especially near the city of Ahemdabad (Gujrat, India) where they congregate annually at the Bahuchara Mata Shrine. Every new initiate to the community has a guru (mentor) and becomes a part of the hijra community once he has paid the dand (fine) to her guru. The amount of the dand is decided by the Panchayat (the community elders, a structure replicated from mainstream Indian society). The notion of the community is key to understanding hijra existence, as it is to many marginalized subcultures, which helps them to belong to a hierarchical frame and survive as a "parallel society" (Turner, 1977).

One of the more complicated and difficult tasks that gender and sexuality scholars face when investigating hijras is that there are several, sometimes contradictory definitions of what makes one a hijra. They have been defined as "eunuchs" (Mehta, 1945; Hiltebeitel, 1980, pp. 161-5; Bobb and Patel, 1982; Sharma, 1984; Preston, 1987; Jaffrey, 1997), "hermaphrodites" (Opler, 1960) with a " physical defect, natural or acquired" (Opler, 1961, p. 1331), male or boy prostitutes (Ellis, 1921; Carstairs, 1956, p.130), passive homosexuals (Carstairs, 1957, p. 60; Greenberg, 1988), and as a third gender and/or sex (Herdt, 1996, p. 70; Nanda, 1996; Nanda, 1999) with a cultural and ritual function (Opler, 1961, p. 1331; Hall, 1997; Nanda, 1999). This is further confounded by most hijra representations in the popular press and cinema being "superficial and sensationalist" (Nanda, 1999, p. xvii) and failing to consider their subjective perceptions (for examples of this sort, see Bobb and Patel, 1982, and Bedi, 1994). Moreover, hijras, homosexuals, and jankhas/ zankhas (transvestites) are often collapsed in the same category (Bakshi, 2002).

Ultimately, any working definition of hijras must take into account their subjective perception as "neither man nor woman" (Nanda, 1999), and as perceived guarantors of fertility whereby their presence at the marriage and birth rituals is legitimated. They belong to the category of 
third gender but also to that of third sex (a point not much emphasized in hijra representations). In contemporary India, ritual and religious respect is not given to them per se, rather they negotiate and command this respect in order to empower their marginal identities in "resistance to systematic exclusion" (Hall, 1997, p. 431). Given that hijras do not have children, there is no simple and comprehensive register of genealogy that can give us details on their ancestors. This is partially due to the fact that as "neither men nor women" hijras have few political rights even though in recent times they have been given the right to vote in democratic elections (BBC News Online, 2000; Times of India, 2002). Thus, the only other source for tracing their beginnings is found in the various myths that have been perpetrated by hijras themselves and other folk literature (songs and chants that are sung during various hijra ceremonies and rituals).

It is interesting to note that transvestism has existed in Hindu mythology even before the conception of humankind and often hijras legitimate their right to existence through a careful decoding of various myths. Almost every hijra has a story of mythological origin relating his/her descendence (Nanda, 1999). For example, most prehistorical myths relate the descent of the hijras from the deity of Shiva (the god of destruction and unparalleled anger), who was also called Ardhanariswar, meaning half man and half woman. For many hijras the quality of being half man and half woman is a source of infinite strength that endows on them the divine power to give a shraap (curse), just like Shiva cursed the earth (Hiltebeitel, 1980, p. 159; Nanda, 1999, p. 20).

In yet another famous myth, during the great war of Kurukshetra (Mahabharata), the most brave and powerful warriors of the Pandava clan Arjun dressed as and became a woman in appearance called Brihannada (Hiltebeitel, 1980, p. 154; Sharma, 1984, p. 384; Nanda, 1999, pp. 30-1). As Brihannada, he participated in the wedding ceremony of his son Abhimanyu with the princess Uttara (Hiltebeitel, 1980, p. 166). It must be pointed out that Arjun's cross-dressing is read by almost all hijras as an instance of voluntary emasculation that opens up avenues of immaculate physical strength.

All hijras stress the notion of impotence as a prerequisite for joining the community and an eventual surgical emasculation for the attainment of divine and physical power. Castration and penectomy are widely practiced as an inevitable requisite for becoming a hijra. Emasculation is looked upon by the hijras as a source of personal fulfillment. Since such practices are illegal and even criminal under the Indian Penal Code, they take place under strict vigilance away from any outside 
(police) encroachments. Hijras regard castration as a ritual, a religious offering of their penis to the Goddess and as a source of pleasure which "re/members (it) as a bloody act and takes the violence as central to the representations of thirdness" (Cohen, 1995, p. 277). In a similar vein, the Travesties of Brazil perceive "the injection of industrial silicone into (their) body" as "one of the final steps . . . in (their) transformation into travesty" (Kulick, 1998, p. 46).

I will now further explore English translations of the word "hijra." It is true that for cultural and gender definition purposes, hijras have been relegated to the categories of eunuchs and hermaphrodites, i.e., emasculated biological males and intersexed "males" whose sexual organs are ambiguous at birth or who suffer from a genetical malformation. However, such definitions seem, at best, to be as subjective definitions of the term "hijra" in various Hindi and urdu linguistic codes implies impotence and is stressed by hijras themselves and has been highlighted by Nanda (1996, p. 380; 1999, p. 13). The definitional importance of impotence gains further weight if we consider that most hijras are born with normal male sexual organs and voluntarily undergo surgical castration to become a part of the hijra community. Nevertheless, the term "Hijra" can still be read as a "eunuch" in the broadest sense of the word, which refers "not only to an individual who is physiologically incapable of engendering an offspring but also to one who has chosen to withdraw from worldly activities and thus refuses to procreate," and are a sanyasi (to use Hindu terminology), someone who voluntarily renounces the world (Ringrose, 1996, p. 86). As I will demonstrate in a moment, definitional understanding of the hijras is quite helpful in better appreciating what sort of gender performance they undertake.

\section{A COMPARATIVE ANALYSIS OF HIJRAS AND DRAG QUEENS}

In recent years queer theory scholars have increasingly focused on how gender and sexuality is performed. Judith Butler's works have been influential to the creation and development of critical analyses and emerging understandings of gender as performance (Butler, 1990). She writes about gender identity as a form cultural fiction, that through "a repeated stylization of the body, a set of repeated acts within a highly rigid regulatory frame that congeal over time to produce the appearance of substance, [become] a natural sort of being" (Butler, 1990, p. 33). She also advocates that drag is a parody of fixed and normative concep- 
tualizations of gender. Ultimately, drag for Butler "constitutes the mundane way in which genders are appropriated, theatricalized, worn, and done; it implies that all gendering is a kind of impersonation and approximation" (Butler, 1991, p. 21).

Drag queens, like Hijra performances, often make us think about the various ways in which gender is played out and "naturalized" in society. They help us to realize that gender is a philosophical category and is not "what one is, but more fundamentally, is what one does" (West and Zimmerman, 1987, p. 140). By exaggerating the feminine, drag queens are capable of showing us the fiction of established dichotomous processes of gendering. Stylization of the self by drag can potentially disrupt regulatory notions of the "self" and can subversively reveal the limits of identity. Perhaps notwithstanding a few movie portrayals, however, most drag queens and their subversive potential are largely marginalized from the larger cultural setting, e.g., most perform in gay bars.

Hijras, on the other hand, enjoy religious and cultural legitimacy. The blessings of hijras in Hindu marriage and birth ceremonies are part of a ritual obligation. This means that the potential "denaturalization" of gender binaries that can be seen in the figure of hijras and their presence at various culturally mainstream rituals is part of the larger social framework in which it occurs. In sum, while drag queens operate in private or alternative social spaces (clubs, bars and lesbian and gay prides), hijras, while still culturally marginalized, perform in normative and conventional cultural spaces.

In hijra performances, however, this alternative space is a priori guaranteed and reinforced by religious and social customs even if the presence of hijras is undesired. Unlike drag shows, hijra performances (although seemingly undertaking a similar deconstruction of gender binaries) take place within mainstream institutions like marriage. Almost all Hindu marriages and birth ritual have ceremonies calling for at least one hijra intervention if not more. Sometimes if the hijras are absent from such ceremonies many newlyweds seek the blessings by going to places where they can find the hijra community. As Andrew Whitehead of the $B B C$ reports in his personal experiences with the hijras, "an Indian birth (is) hardly complete without the hijras" (Whitehead, 1998).

Let me now explore the relational aspect of hijra shows. The audience of hijra performances usually comprises everyone present at the concerned weddings. It consists of almost all adult male and female relatives, and even children. Unlike the audiences at drag shows, this mainstream public of hijra shows is paradoxically often not fully pre- 
pared for a "visible attack" (in the form of a dance-spectacle) on their preconceived notions of rigid gendered and sexed identities. The alternative space which the hijra performs in, and which has the capacity to demythify gender identities, is often negotiated and at times coerced by the hijras in the presence of an involuntary audience who can sometimes refuse that the hijras lift up their ghagras (long skirts) or saris.

One of the most fascinating aspects of the audience/hijra interaction is that men in the audience both regulate and control the hijra performance/transgression. Women are relegated to the subordinate rank of mere spectators while the patriarchal figures of the household (father, uncle or a distant male relative) deal with the performers. Men are responsible for negotiating and fixing the boundaries concerning the duration of the shows, the financial compensation of the hijras, and most importantly, the sexual gestures involved in the hijra performance. In this sense, males in the audience (married or otherwise) represent stability and order of gendered identities and are the monolithic guarantors of the continuation of these identities. Nevertheless, they participate in such an exceptional exchange with the hijras (often in a climate charged with sexual dynamics) who represent a challenge to this very notion of normative identity regulation. The hijra performance thus becomes a discursive site of critical negotiations between the symbolic patriarchs and alternatively (inter-)sexed beings. This site reveals the fiction of gendered and sexed realities where gendering and sexualizing forces (in the figure of the patriarchs) play and are played out (in the figure of the hijras, who enact both the feminine and the masculine parts in case the males present in the ceremonies refuse to take part in their song and dance sequences). This dramatic transgression of normativity subsides once the hijra ceremony is over and the males from the audience (who are often the receivers of hijra attention/irony) return to their constructed role of controlling the gender boundaries but not without a sense of pleasure.

Critical commentators on drag have begun to question the attribution of the unproblematic subversion of heteronormative ideals to the figure of drag. Drag, it has been suggested, is not a simple tool of resistance to preexisting gender/sexual dichotomies and, thus, cannot be set up as a uniquely radical and unified category that has the possibility (and the power) to critique identity limits. Even Butler, who proposed drag as a subversive undertaking, has repositioned drag as a potential threat to an exposure of gender fictions rather than being the unquestioned source of resistance to such fictions in itself. In one of her later works she clarifies that drag is never "unproblematically subversive" and it "reflects 
the mundane impersonations by which heterosexually ideal genders are performed and naturalized." Moreover, she emphasizes that drag has the potential to "reidealize heterosexual norms without calling them into question" (Butler, 1993, p. 231).

Other queer scholars have even inquired into various ways in which discussions on drag in queer theory have significantly centered around "play" and "performance" thus reducing the very "theory of gender" into the "old "sex roles' framework" (Walters, 1996, p. 854). In the domain of transgender studies scholars have argued that transgender individuals often "reinforce and reify the system they hope to change" and that "female impersonators almost universally present stereotypical and exaggerated images of females" (Gagné, Tewksbury and McGaughey, 1997, p. 478; Tewksbury, 1993, p. 467). Even in studies of third gender, the male/female binary divide is suspected to be reinstated as if it "recuperates social and sexual norms," to borrow a phrase from Garber (Garber, 1992, p. 69; Kulick, 1998, p. 120).

In order to better understand the critical implications of drag in issues of political and social resistance, one needs to (re)view gender and gendering as intellectual sites where the power dynamic of male/female, straight/gay, superior/inferior, original/duplicate is at work. In other words, all contemporary gender relationships are hegemonically structured around the possession of power. Apart from the play and performance that one links to drag, we must also (re-)locate drag in a broader context of the power problematic. I believe that at a non-complex level, drag relies heavily on the ability to shock and scandalize. The techniques for resisting pre-given identity limits used by drag queens mostly consist of an exaggeration and a deliberate overplay of the "feminine." This can certainly be read as an instrument of "male" power so that men can pose as, and seemingly be, "better" women than women themselves. Drag may tell us how gendered identity is constructed by cultural and social conditioning but it also paradoxically often re-legitimates gender as an essential category with its focus on exaggerated forms of the feminine. Drag, as Schacht argues, is often a form of "homosexual embodiment of the heterosexual," whereby a drag performance often fixes and reinstates the gender binary rather than exposing it. Read in this way drag shows "become wholly dependent on the audience's normative expectations about gender and sexuality" and are "frequently more reflective than transgressive of the dominant culture's ideals of gender and sexuality" (Schacht, 2002, p.163).

Thus, while drag is not unconditionally subversive, the hijra paradigm forces us to rethink about the multiplicity of the techniques of re- 
sistance to preexisting gender identifications. Shock and scandal are also used in the hijra shows as tools for unsettling gender equations. The audiences are generally involuntary participants in the performances as hijra shows are an unwritten dictate of the cultural context. Once the song and dance sequences are over, the hijras invariably lift up their ghagras or saris (unless warned not to do so by the adult male members of the audience), to show that they are male (i.e., possess a male organ) or that they are neither male nor female (i.e., have no sexual organ) as in most cases. This is often done to show that the hijras are "real" hijras (i.e., are castrated), and not fake ones (i.e., men posing as hijras), or just effeminate men, zenanas, for whom the hijra community reserves disdain (Cohen, 1995, p. 276; Jaffrey, pp. 110 and 161; Nanda, 1999, p.11). However, sometimes if the marriage party refuses to pay the desired alms to the hijras, they can use it as a tool to demand their rights. As Cohen puts it, "the sight of the postoperative hole-the seal of the hijras impotence-is paradoxically potent, causing impotence in the man who is exposed to it" (Cohen, 1995, p. 296, italics in original).

The lifting of the sari can be accompanied by their shraap or other verbal assaults. Various responses can be given to the hijra insults. Some scholars, like Sharma, think that these insults are the result of hijras" "sexual frustration," while others have argued it is a tried and tested technique for extorting money (Carstairs, 1956, p. 130; Sharma, 1984, p. 387). Yet others consider these insults a legitimate replication of societal intimidation and dehumanization (Mehta, 1945, pp. 47-8; Jaffrey, 1997, p. 241). It should nevertheless be noted that hijra linguistic remarks, though strikingly harsh, form a part of the larger background of their performance. Any drag quarrels remain within closed spaces while the hijra "vituperative banter" is often in the presence of non-hijra males with the aim to "embarrass their male listeners and shamelessly collapse traditional divisions of the secret and the known, private and public, home and market, feminine and masculine" (Hall, 1997, pp. 448-9). Moreover, hijras, like other marginalised and liminal entities, can escape from principal conditions of propriety imposed by social control (Turner, 1977).

Once the hijras lift up their saris, the audience who is seduced into believing that they are witnessing a "female" show often experiences a shock. The myth of seeing a seemingly "female performance" ends abruptly with this gesture. The "incongruity" of sexual and gendered identity that is part of identity politics and identity fiction becomes a "visible" reality. What the audience witnesses and participates in is not only the shock of seeing/not seeing the sexual parts (for many prudish 
Indians) but also a demonstrative deconstruction of stabilized gender identities.

This effective de-mythification of the "incongruity" of gendered identities becomes all the more meaningful and interesting if we analyze the figure of hijra itself. Unlike many drag queens, many hijras are visible manifestations of the fiction of gender in their person. Some of them do use the masculine attributes when talking of themselves or addressing each other. Some also have masculine names even if this is rare. Almost all of them that I have met or seen always retain their dry and hard masculine voices while at the same time wearing female attires. Even during hijra shows they do not aim at acquiring a high pitched female voice and it is this very disturbing aspect of their appearance that becomes a dynamic tool for resisting the male/female divide and helps them to disrupt in part the semblance of a "female" performance. If the "body" is an essential component of identity through which "we announce our presence to others," then the 'incongruent' hijra body that belongs to third sex poses a real threat to established sexual dimorphism (Gagné and Tewksbury, 1998, p. 85). The fear of this incongruity is pervasive in the film Darmiyaan; when Immi the hijra (as a child) unbuttons his trousers to pee, one of the other children remarks: "Immi ka to nounou hi nahi hai," i.e., Immi does not have a penis.

The hijra body and paradigm, so nebulous, can extend anywhere from an emasculated male to a withdrawn or effeminate one right up to a sanyasi. It covers the entire spectrum from the holy to the bizarre to the damned! There is so much irony in this spectrum that one form of the hijra is revered as the sanyasi and one is marginalised if not always rebuked or ridiculed in the form of the outlandish "eunuch" in urban India. However, in all this irony there lies a grave similarity. In all its forms, the hijra is certainly also feared. In some cases the fear arises out of psychological insecurities, while in some it may arise out of anxiety of the unknown. But it is fear all the same. And yet culturally we tend to associate the archetype of the hijra with the powerless!

\section{GENDERED (IN)SECURITIES}

Studying alternative sex and gender matrices of the Orient involves an unsettling of accepted American and Eurocentric ideas as the only available cultural referent, and debunking sexual and gendered dimorphism across cultures. Transgendered communities found across cultures are suggestive of "a continuum of masculinity and femininity, 
renouncing gender as aligned with genitals, body, social status and/or role" (Bolin, pp. 447-8). Drag queen and hijras performances open up spaces where we as a larger society "can watch a small group and become aware" of ourselves and understand that all "performance is an illusion . . . and might be considered more 'truthful,' more 'real' than ordinary experience" (Schechner, 1988, pp. xiv and 13).

Reading the hijra alongside the drag queen means broadening and enriching the discursive elements of identity (in)congruity and revealing the fiction of all gendering and sexualizing processes of any dominant culture. Gender and sexuality debates, as I have shown, have centered upon drag or hijras as two distinct cultural categories that unsettle our preconceived notions of the masculine and the feminine. Both are subcultural byproducts of Western and Indian societies and have developed in relation to their respective mainstream cultures. The drag queen and the hijra have different modus operandi but both appear to have the same goal of de-legitimizing polarized and normalizing gender categories. While the drag queen typically performs in marginalized settings, hijras have the right to perform in mainstream cultural ceremonies. Yet both have a limited impact on the larger culture. Drag queens are individuals with an acknowledged penis whereas hijras are framed as impotent and eunuchs. Thus, the subversive potential of drag is undermined by limiting their performances to marginalized settings, whereas that of the hijras is limited because of their marginalized status of being impotent and lacking a penis. Ultimately, while both the hijras and the drag queen have a limited subversive impact on the larger dominant culture in which they perform, in practice and image they can forcibly remind us of our own gendered (in)securities.

\section{REFERENCES}

Bakshi, S. (2002). Soupçon d'un Espace Alternatif: Etude de Deux Films du Cinéma Parallèle en Inde. Inverses, 2, 9-21.

$B B C$ News Online (2000, March 6). Eunuch MP takes seat.

$B B C$ News Online (2001, March 9). India stages Ms World for eunuchs.

Bedi, R. (1994, April 16). The bizarre and dangerous world of India's eunuchs. Vancouver Sun.

Bobb, D., and Patel, C.J. (1982, September 15). Fear is the key. India Today.

Bolin, A. (1996). Transcending and transgendering: Male to female transsexuals, dichotomy and diversity. In Gilbert Herdt (Ed.) Third sex/third gender: Beyond sexual dimorphism in culture and history (pp. 447-486). New York: Zone Books. 
Butler, J. (1990). Gender trouble: Feminism and the subversion of identity. New York: Routledge.

Butler, J. (1991). Imitation and gender insubordination. In D. Fuss (Ed.), Inside/out: Lesbian theories/gay theories (pp.13-31). New York: Routledge.

Butler, J. (1993). Bodies that matter: On the discursive limits of "sex." New York: Routledge.

Carstairs, G.M. (1956). Hinjra and jiryan: Two derivatives of Hindu attitudes to sexuality. British Journal of Medical Psychology, 29, 128-138.

Cohen, L. (1995). The pleasures of castration: The postoperative status of hijras, jankhas, and academics. In P.R. Abramson and S.D. Pinkerton (Eds.), Sexual nature, sexual culture (pp. 276-304). Chicago and London: University of Chicago Press.

Gagné P., and Tewksbury, R. (1998). Conformity pressures and gender resistance among transgendered individuals. Social Problems, 45(1), 81-101.

Gagné P., Tewksbury, R., and McGaughey D. (1997). Coming out and crossing over: Identity formation and proclamation in a transgender community. Gender and Society, 11(4), 478-508.

Garber, M. (1992). Vested interests: Cross-dressing and cultural anxiety. London and New York: Routledge.

Greenberg, D.F. (1988). The construction of homosexuality. Chicago: University of Chicago Press.

Hall, K. (1997). Go suck your husband's sugarcane: Hijras and the use of sexual insult. In A. Livia and K. Hall (Eds.), Queerly phrased: Language, gender and sexuality (pp. 430-460). New York: Oxford University Press.

Hiltebeitel, A. (1980). Siva, the Goddess, and the disguises of the Pandavas and Draupadi. History of Religions, 20(1-2), 147-174.

Jaffrey, Z. (1997). The invisibles: A tale of the eunuchs of India. London: Weidenfeld and Nicholson.

Kulick, D. (1998). Travesti: Sex, gender and culture among Brazilian transgendered prostitutes. Chicago: University of Chicago Press.

Mehta, S. (1945). Eunuchs, pavaiyas, and hijaras. Gujarat Sahitya Sabha Part 2, 3-75.

Nanda, S. (1996). Hijras: An alternative sex and gender role in India. In Gilbert Herdt (Ed.), Third sex/third gender (pp. 373-418). New York: Zone Books.

Nanda, S. (1999). The hijras of India: Neither man nor woman. Second Edition. Belmont: Wadsworth.

O'Flaherty, W.D. (1980). Women, androgynes, and other mythical beasts. Chicago: University of Chicago Press.

Opler, M.E. (1960). The hijara (hermaphrodites) of India and Indian national character: A rejoinder. American Anthropologist, 62, 505-511.

Opler, M.E. (1961). Further comparative notes on the hijara of India. American Anthropologist, 63, 1331-1332.

Preston, L.W. (1987). A right to exist: Eunuchs and the state in nineteenth-century. Modern Asian Studies, 21(2), 371-387.

Ringrose, K.M. (1996). Living in the shadows: Eunuchs and gender in Byzantium. In Gilbert Herdt (Ed.), Third sex/third gender (pp. 85-109). New York: Zone Books. 
Schacht, S.P. (2002). Four renditions of doing female drag: Feminine appearing conceptual variations of a masculine theme. Advances in Gender Research, 6, 157-180.

Sharma, S.K. (1984). Eunuchs: Past and present. Eastern Anthropologist, 4, 381-389.

Tewksbury, R. (1993). Men performing as women: Explorations in the world of female impersonators. Sociological Spectrum, 13, 465-486.

The Times of India (2002, June 20). Eunuch elected ward councilor in Bihar.

Turner, Victor W. (1977). The ritual process: Structure and anti-structure. Chicago: Adline.

Walters, Suzanna D. (1996). From here to queer: Radical feminism, postmodernism, and the lesbian menace (or, why can't a woman be more like a fag?). Signs, 21(4), 830-869.

West C., and Zimmerman, D.H. (1987). Doing gender. Gender and Society, 1, 125-151.

Whitehead, Andrew. (1998, August 16). The hijras' blessing. BBC News Online. 